\section{Baylor faculty upset over science and religion center}

One year after a Kansas Board of Education banned the study of evolutionary biology in its public schools, the latest clash between evolutionists and creationists-those who believe God created life-has erupted at Baylor University in Waco, Texas. At issue is the establishment of the new Michael Polanyi Center, which aims to be an "an active participant in the growing dialogue between science and religion."

Critics say Baylor's president, Robert B. Sloan Jr., set up the program with no formal input from the faculty, and they are perturbed that it will be dominated by proponents of 'intelligent design', a theory that draws on physics, mathematics and philosophy to argue that living things are so complex, evolution could not have produced them. Thus, life had to have been the work of a higher power. The center's director, William Dembski, is one of

\section{Australia to create biomedical lobby group}

Australia wants to emulate the US success story Research!America by setting up the country's first umbrella group for grassroots community advocacy of medical research. Stakeholders in Research Australia held an inaugural meeting last month, securing broad support from research institutes, disease foundations, the pharmaceutical and biotechnology sector and the Australian Stock Exchange (ASX).

The creation of a body to engage the public in setting the scientific agenda follows the federal government's endorsement last year of the Wills report, chaired by Garvan Institute of Medical Research chairman Peter Wills (Nature Med. 5 9; 1999). At the time, Prime Minister John Howard indicated that he was "attracted to how this is done in the US through the Research!America alliance." Wills told Nature Medicine, "Now I've taken the baton and run with it." He says although inspired by the "simplicity and power" of the US lobby, the Australian version would be tailored to reflect different political and social realities and would advocate for public health as well as laboratory research.

Since its inception in 1989, Research! America has lobbied congressional members relentlessly, commissioned public opinion polls, funded advertising campaigns and sponsored awards, all to boost research dollars. Its muscle has been rec- the theory's chief proponents.

Unlike creation science, which holds that scientific evidence proves the Bible's creation story, 'intelligent design' stops short at giving God credit and shies away from biblical references. Still, some Baylor science faculty argue that 'intelligent design' is a fringe theory that doesn't have any real standing in the academic community. "We are mainstream scientists and we're concerned that the Polanyi center casts us as something than other than that," says Charles Weaver, an associate professor of neuroscience and psychology.

"The directors of the center claim to be doing science; that is, they argue for introducing intelligent design into science as an explanatory category," Robert Baird, chairman of the Faculty Senate, wrote in the senate's newsletter. "Yet the Center was created without consultation

ognized by the Wall Street Journal, which reported, "the driving force behind the huge $15 \%$ increase in the NIH budget to US\$15.6 billion (in 1998) was an umbrella organization called Research! America." Wills believes corporate philanthropy and government spending will increase in response to the enthusiasm of ordinary Australians, with polls already showing $80 \%$ of people want to hear more about medical research.

The ASX wants to play a lead part in encouraging the diversion of some corporate sponsorship dollars from sport and the arts to medical research, says Michael Roche of ASX. It will offer seed funding to Research Australia, whose initial operating budget is estimated at $\mathrm{A} \$ 500,000$ (US\$290,000).

The Australian Society for Medical Research backs the new group, pledging that far from the prospect of a 'turf war', its members look forward to benefiting from a broadening of the base of political and corporate support for medical research. "At this point there's plenty of people within the research sector who are active, but the public hasn't been involved, and that's the key distinction," says ASMR board member Peter Schofield. A business plan for Research Australia will be drawn up by August, with a formal launch later in the year.

Rada Rouse, Brisbane with colleagues in the sciences."

Sloan rejected a $26-2$ vote by the senate to dissolve the center, and instead is putting together a review committee to study the issues raised by faculty. In an official statement, Sloan says he rejects creation science and would never bar anyone at Baylor from teaching evolution. He does, however, believe that God created the world.

Baylor, which houses an Institute of Biomedical Studies in affiliation with Baylor College of Medicine, is the country's largest Baptist university. The school's commitment to the sciences includes plans for a new $\$ 60$ million science building and $\$ 20$ million in renovations to existing laboratories. The director of the biomedical institute, Darden Powers, who is also chairman of the physics department, says he supports the president's position on the Polanyi center but declined to comment further.

The clash comes at a time when an increasing number of universities are revisiting the uneasy relationship between religion and science. Programs range from the American Association for the Advancement of Science's decidedly proevolution "Dialogue on Science, Ethics and Religion," to the three-year-old God and Computers course and lecture series at the Massachusetts Institute of Technology, to the graduate school program at the Institute for Creation Research in southern California.

Tinker Ready, Boston

With only weeks to go before the biennial World AIDS Conference begins in Durban, South Africa (9-12 July), stakeholders in the sub-Saharan epidemic are increasing their activities. President Thabo Mbeki's controversial advisory panel of AIDS 'experts' (Nature, 405, 105; 2000) will present its report on the reasons for the spread of the disease in the region prior to the start of the meeting. Meanwhile, an 11 May Executive Order by President Bill Clinton, announcing that the US will allow sub-Saharan Africa special leeway to import and manufacture patented AIDS drugs, plus a same-day statement by five leading pharmaceutical companies and UNIADS that they will slash the price of AIDS drugs to Africa, may calm potentially vociferous demonstrations by activists.

Nature Medicine will be in Durban covering the conference-proposed boycott by the World's HIV scientists permitting - to bring you news of the meeting via our website at www.medicine.nature.com and in the next issue of the journal. 